\title{
PENGARUH UKURAN PERUSAHAAN, LEVERAGE, UKURAN DEWAN KOMISARIS DAN PROFITABILTAS TERHADAP PENGUNGKAPAN CORPORATE SOCIAL RESPONSIBILITY \\ (STUDI EMPIRIS PADA PERUSAHAAN PERTAMBANGAN YANG GO PUBLIC TAHUN 2016-2018 DI BURSA EFEK INDONESIA)
}

\author{
Andry Sugeng \\ Program Studi Akuntansi, Ekonomi, Universitas Pamulang, Jl. Surya Kencana No. 1, Tangerang Selatan, 15412, \\ Indonesia \\ E-mail: dosen02507@unpam.ac.id
}

\begin{abstract}
This study aims to analyzie and obtain empirical evidence about the effect company size, leverage, board of commisioners and profitability on the corporate social responsibility disclosure to coal mining companies in Indonesia. The independent variables of this study are company size, leverage, board of commisioners, and profitability while the dependent variable of this study is the disclosure of corporate social responsibility. The study conducts multiple regression analysis by using mining companies which listed in the Indonesia Stock Exchange (BEI) over period between 2016 to 2018 with a total of 44 companies. This study collects the data by purposive sampling method that makes the total sample is 17 companies with 51 data of financial statements companies as research observations. This study finds that: (1) company size not significant effect to corporate social responsibility disclosure;(2) leverage not significant effect to corporate social responsibility disclosure;(3) board of commisioners not significant effect to corporate social responsibility disclosure; and (4) profitability significantly effect to corporate social responsibility disclosure.
\end{abstract}

Keywords: size; leverage; board of commissioners; profitability; CSR

\section{PENDAHULUAN}

Corporate Sosial Responsibility (CSR) merupakan jawaban atas inisiatif bahwa bisnis tidak hanya berjalan demi kepentingan shareholders belaka, tetapi juga stakeholders, termasuk di dalamnya antara lain adalah konsumen, karyawan, pemasok, masyarakat di sekitar dan juga pemerintah. CSR menunjukkan suatu komponen penting dan komitmen yang luas terhadap pembangunan untuk berkelanjutan dimana Global Compact Initiative meyebut pemahaman ini sebagai 3P atau dikenal dengan "tripple bottom line" (people, profit, planet). Meski tujuan bisnis adalah laba (profit), perusahaan harus bisa mensejahterakan semua orang (people) dan kelestarian bumi (planet) ini. CSR merupakan salah satu kewajiban yang harus dilaksanakan oleh suatu perusahaan yang sesuai dengan isi Pasal 74 dari Undang-Undang Perseroan Terbatas No. 40 Tahun 2007. Undang-undang tersebut mewajibkan perusahaan yang melakukan kegiatan usaha di bidang/berkaitan dengan sumber daya alam melakukan tanggungjawab sosial dan lingkungan.

Perusahaan sebagai pengguna sumber daya alam terbesar harus mampu mengelola serta memelihara secara berkelanjutan demi kepentingan ekonominya. Aktifitas perusahaan yang awalnya hanya diukur dengan hanya mengedepankan laba kini mulai beralih memperhitungkan masalah sosial dan lingkungan dalam laporan keuangan mereka. Krivačić (2017) mengungkapkan bahwa laporan keuangan bukan hanya berfokus atas data finansial dan historis saja namun juga berfokus pada pelaporan non finansial. Perubahan paradigma tersebut disebabkan oleh begitu banyaknya dampak kerusakan lingkungan yang ditimbulkan oleh perusahaan. Perusahaan pertambangan merupakan salah satu perusahaan yang dianggap memiliki limbah yang berpotensi mengganggu kelestarian lingkungan. Kegiatan 
pertambangan meliputi kegiatan dalam rangka penelitian material, pengelolaan mineral tambang yang meliputi penyelidikan umum, eksplorasi, studi kelayakan, konstruksi, penambangan, pengelolaan dan pemurnian, pengangkutan dan penjualan, serta kegiatan pasca tambang. Kegiatan pertambangan tersebut merupakan kegiatan yang bergerak di bidang pemanfaatan sumber daya alam yang secara langsung maupun tidak langsung dapat berpengaruh terhadap lingkungan sekitar perusahaan tambang tersebut seperti pencemaran polusi dan limbah yang menyebabkan perusahaan tambang sering di pandang tidak sesuai oleh masyarakat sekitar pertambangan (Wahyuningsih dan Mahdar, 2018).

Kerusakan lingkungan memunculkan tuntutan untuk kegiatan bisnis agar lebih ramah terhadap lingkungan. Perusahaan diminta untuk bertanggungjawab atas lingkungan dan sosial melalui sebuah laporan yang bersifat non keuangan yaitu laporan CSR. Loh et al. (2017) menyatakan bahwa investor mulai tertarik pada perusahaan yang melaporkan aktifitas sosial dan lingkungannya. Pelaporan pertanggungjawaban sosial dan lingkungan dianggap dapat menanamkan disiplin dan membantu perusahaan untuk meningkatkan kesadaran akan praktik keberlanjutan yang dapat dijadikan visi jangka panjang perusahaan (ACCA, 2013). CSR merupakan perwujudan kontribusi perusahaan untuk ikut serta dalam mewujudkan pembangunan yang berkelanjutan (Ambarini, 2010). Burhan dan Rahmawati (2012) menyatakan bahwa berinvestasi pada organisasi yang memiliki pertanggungjawaban sosial akan lebih baik dibandingkan dengan organisasi yang memiliki profit tinggi tetapi mengabaikan lingkungan. Perusahaan yang melakukan pengungkapan sosial yang lebih baik akan memiliki nilai pasar yang lebih baik dan menghasilkan manfaat yang diharapkan untuk meningkatkan arus kas perusahaan (Shaukat et al., 2016).

Kinerja keuangan perusahaan merupakan faktor penting untuk menilai keseluruhan kinerja perusahaan itu sendiri, dimulai dari penilaian aset, utang, likuiditas, dan lain sebagainya. Banyak indikator yang dapat digunakan dalam menganalisis kinerja keuangan perusahaan antara lain cash flow atau aliran dana per transaksi, profitabilitas, likuiditas, struktur keuangan dan investasi atau rasio pemegang saham. Adanya penyampaian informasi kinerja ketaatan pengelolaan lingkungan secara informatif kepada stakeholders dan publik sangat diperlukan, sekaligus agar perusahaan dapat membantu tercapainya kesejahteraan stakeholders dan mencapai laba maksimum (Susilatri et al., 2011).

Perusahaan besar memiliki biaya keagenan yang lebih besar sehingga mempunyai insentif lebih untuk mengungkapkan informasi yang lebih luas. Perusahaan yang memiliki jumlah aset yang lebih besar lebih mampu membiayai penyediaan informasi pertanggung jawaban sosialnya dibanding perusahaan yang asetnya lebih kecil atau rendah (Ruroh dan Latifah, 2018). Dalam rangka mengurangi biaya keagenan tersebut, perusahaan besar juga lebih banyak dilihat sehingga pengungkapan yang lebih besar merupakan pengurangan biaya politis sebagai wujud tanggungjawab sosial perusahaan. Secara teoritis, perusahaan besar tidak akan lepas dari tekanan, dan perusahaan yang lebih besar dengan aktivitas operasi dan pengaruh yang lebih besar terhadap masyarakat mungkin akan memiliki pemegang saham yang memperhatikan program sosial yang dibuat perusahaan sehingga pengungkapan tanggungjawab sosial perusahaan akan semakin luas (Nur dan Priantinah, 2012). Nur dan Priantinah (2012) maupun Ruroh dan Latifah (2018) menunjukkan bahwa ukuran perusahaan berpengaruh positif signifikan terhadap pengungkapan tanggungjawab sosial.

Perusahaan yang mempunyai tingkat leverage tinggi berarti sangat bergantung pada pinjaman luar untuk membiayai asetnya sedangkan perusahaan yang mempunyai tingkat leverage yang rendah lebih banyak membiayai asetnya dengan modal sendiri. Perusahaan yang berisiko tinggi biasanya berusaha untuk meyakinkan kreditur dengan pengungkapan yang lebih detail. Tambahan informasi diperlukan untuk menghilangkan keraguan terhadap dipenuhinya hak-hak kreditur. Oleh karena itu perusahaan dengan leverage yang tinggi memiliki kewajiban mengungkapkan CSR dibanding dengan perusahaan leverage rendah 
(Ruroh dan Latifah, 2018). Manajemen perusahaan dengan tingkat leverage yang tinggi cenderung mengurangi pengungkapan tanggung jawab sosial yang dibuatnya agar tidak menjadi sorotan dari para debtholders (Nur dan Priantinah, 2012).

Dewan komisaris merupakan wakil shareholder dalam entitas bisnis yang berbadan hukum Perseroan Terbatas (PT) yang berfungsi mengawasi pengelolaan perusahaan yang dilaksanakan oleh manajemen (direksi), dan bertanggungjawab untuk menentukan apakah manajemen memenuhi tanggungjawab mereka dalam mengembangkan dan menyelenggarakan pengendalian intern perusahaan. Dengan wewenang yang dimiliki, dewan komisaris dapat memberikan pengaruh yang cukup kuat untuk menekan manajemen agar mengungkapkan informasi CSR lebih banyak sehingga dapat dijelaskan bahwa perusahaan yang memiliki ukuran dewan komisaris yang lebih besar akan lebih banyak mengungkapkan CSR. Sebagai wakil dari prinsipal di dalam perusahaan, dewan komisaris dapat mempengaruhi luasnya pengungkapan tanggung jawab sosial karena dewan komisaris merupakan pelaksana tertinggi di dalam entitas. Ukuran dewan komisaris diukur dengan jumlah anggota dewan komisaris, dimana semakin banyak jumlah dewan komisaris perusahaan maka semakin mudah untuk melakukan pengawasan pada tingkatan manajemen dibawahnya (Sembiring, 2003).

Sesuai dengan teori legitimasi, semakin tinggi profitabilitas perusahaan, maka perusahaan tersebut akan semakin mengungkapkan informasinya untuk menunjukkan perhatiannya kepada masyarakat. Semakin tinggi profitabilitas suatu perusahaan, maka manajer lebih termotivasi untuk memberikan informasi yang lebih terperinci termasuk kebebasan untuk menunjukkan dan mempertanggungjawabkan seluruh program sosialnya. Hal ini juga menyebabkan manajer ingin meyakinkan investor akan profitabilitas perusahaan yang tinggi (Ruroh dan Latifah, 2018).

\section{TINJAUAN PUSTAKA}

Teori stakeholder. Stakeholder adalah sistem yang secara eksplisit berbasis pada pandangan tentang suatu organisasi dan lingkungannya, mengakui sifat saling mempengaruhi antara keduanya yang kompleks dan dinamis. Stakeholder dan organisasi saling mempengaruhi, hal ini dapat dilihat dari hubungan sosial keduanya yang berbentuk responsibilitas dan akuntabilitas. Oleh karena itu organisasi memiliki akuntabilitas terhadap stakeholdernya. Menurut Ghozali dan Chariri (2007:409), teori stakeholder merupakan teori yang menyatakan bahwa perusahaan bukanlah entitas yang hanya beroperasi untuk kepentingan sendiri namun harus memberikan manfaat kepada seluruh stakeholder-nya (pemegang saham, kreditor, konsumen, supplier, pemerintah, masyarakat, analis, dan pihak lain). Kelompok stakeholder inilah yang menjadi bahan pertimbangan bagi manajemen perusahaan dalam mengungkap atau tidak suatu informasi di dalam laporan perusahaan tersebut. Tujuan utama dari teori stakeholder adalah untuk membantu manajemen perusahaan dalam meningkatkan penciptaan nilai sebagai dampak dari aktivitas-aktivitas yang dilakukan dan meminimalkan kerugian yang mungkin muncul bagi stakeholder.

Teori legitimasi. Legitimasi merupakan proses bagaimana suatu entitas pelapor berusaha memperoleh, menjaga, memelihara atau memperbaiki legitimasi organisasi di mata para stakeholder-nya (Lindblom, 1994). Ketika melakukan proses legitimasi, penggunaan strategi pengungkapan membentuk opini atau apa yang dirasakan dan dipikirkan oleh stakeholder tentang entitas pelapor. Lindblom (1994) menyatakan bahwa suatu organisasi mungkin menerapkan empat strategi legitimasi ketika menghadapi berbagai ancaman legitimasi. Oleh karena itu, untuk menghadapi kegagalan kinerja perusahaan seperti kecelakaan yang serius atau skandal keuangan organisasi mungkin:

1) Mencoba untuk mendidik stakeholder-nya tentang tujuan organisasi untuk meningkatkan kinerjanya. 
2) Mencoba untuk merubah persepsi stakeholder terhadap suatu kejadian (tetapi tidak merubah kinerja aktual organisasi).

3) Mengalihkan (memanipulasi) perhatian dari masalah yang menjadi perhatian (mengkonsentrasikan terhadap beberapa aktivitas positif yang tidak berhubungan dengan kegagalan-kegagalan).

4) Mencoba untuk merubah ekspektasi eksternal tentang kinerjanya.

Keempat strategi tersebut dapat dilakukan dengan cara mengungkapkan informasi perusahaan kepada publik, seperti pengungkapan dalam laporan tahunan. Perusahaan dapat mengungkapkan informasi-informasi yang dapat memperkuat legitimasinya, misalnya dengan menyebutkan penghargaan-penghargaan lingkungan yang pernah diraih atau program-program keselamatan yang telah diterapkan perusahaan jika mereka ingin mendapat legitimasi dari stakeholder-nya. Langkah yang sama juga dilakukan jika perusahaan ingin mendapat legitimasi dari pemegang saham. Hal tersebut dilakukan dengan mengungkapkan keunggulan saham perusahaan, prospek laba dan sebagainya. Ketika perusahaan memiliki tingkat laba yang tinggi, perusahaan (manajemen) menganggap perlu melaporkan hal-hal yang dapat mengganggu informasi tentang sukses keuangan perusahaan. Mereka berharap para pengguna laporan keuangan membaca "good news" kinerja sosial dan lingkungan yang dilakukan perusahaan (Sembiring, 2003). Melalui pengungkapan, perusahaan juga dapat mengklarifikasi atau bahkan membantah berita-berita negatif yang mungkin muncul di media.

Pengungkapan Corporate Social Responsibility (CSRI). Pengungkapan adalah pengeluaran informasi yang ditujukan bagi pihak-pihak yang berkepentingan. Tujuannya adalah agar perusahaan dapat menyampaikan tanggungjawab sosial yang telah dilaksanakan dalam periode tertentu. Penerapan CSRI dapat diungkapkan perusahaan melalui laporan tahunan (annual report). Laporan tanggungjawab sosial merupakan laporan aktivitas tanggungjawab sosial yang telah dilakukan oleh perusahaan baik berkaitan dengan perhatian masalah dampak sosial maupun lingkungan. Laporan tersebut menjadi bagian yang tak terpisahkan dengan laporan tahunan yang dipertanggungjawabkan direksi di depan sidang Rapat Umum Pemegang Saham (RUPS). Laporan ini berisi laporan programprogram sosial dan lingkungan perseroan yang dilaksanakan selama tahun buku berakhir (Hadi, 2011:206).

Ukuran perusahaan (size). Ukuran perusahaan merupakan variabel yang banyak digunakan untuk menjelaskan pengungkapan sosial yang dilakukan perusahaan dalam laporan tahunan yang dibuat. Secara umum, perusahaan besar akan mengungkapkan informasi lebih banyak dari pada perusahaan kecil. Hal ini karena perusahaan besar akan menghadapi risiko politis yang lebih besar dibandingkan perusahaan kecil. Secara teoritis, perusahaan besar tidak akan lepas dari tekanan, dan perusahaan yang lebih besar dengan aktivitas operasi dan pengaruh yang lebih besar terhadap masyarakat mungkin akan memiliki pemegang saham yang memperhatikan program yang dibuat perusahaan sehingga pengungkapan tanggungjawab sosial perusahaan semakin luas (Nur dan Priantinah, 2012). Penelitian yang dilakukan oleh Nur dan Priantinah (2012) maupun Ruroh dan Latifah (2018) menunjukkan bahwa ukuran perusahaan berpengaruh positif signifikan terhadap pengungkapan tanggungjawab sosial. Secara teoritis, perusahaan besar tidak akan lepas dari tekanan politis, yaitu tekanan untuk melakukan pertanggungjawaban sosial. Pengungkapan sosial yang lebih besar merupakan pengurangan biaya politis bagi perusahaan (Cahya, 2010). Oktariani dan Mimba (2014) menunjukkan bahwa ukuran perusahaan tidak berpengaruh terhadap pengungkapan tanggungjawab sosial perusahaan.

Leverage. Menurut Kasmir (2014:157), leverage merupakan rasio yang digunakan untuk mengukur sejauh mana aktiva perusahaan dibiayai denga utang, berapa besar beban utang yang ditanggung perusahaan dibanding dengan aktivanya. Menurut Ruroh dan 
Latifah (2018), perusahaan yang mempunyai tingkat leverage tinggi berarti sangat bergantung pada pinjaman luar untuk membiayai asetnya. Sedangkan perusahaan yang mempunyai tingkat leverage yang rendah lebih banyak membiayai asetnya dengan modal sendiri. Perusahaan yang berisiko tinggi biasanya berusaha untuk meyakinkan kreditur dengan pengungkapan yang lebih detail. Tambahan informasi diperlukan untuk menghilangkan keraguan terhadap dipenuhinya hak-hak kreditur. Oleh karena itu, perusahaan dengan leverage yang tinggi memiliki kewajiban mengungkapkan CSR dibandingkan dengan perusahaan leverage yang rendah (Ruroh dan Latifah, 2018). Manajemen perusahaan dengan tingkat leverage yang tinggi cenderung mengurangi pengungkapan tanggungjawab sosial yang dibuatnya agar tidak menjadi sorotan dari para debtholders (Nur dan Priantinah, 2012). Penelitian yang dilakukan oleh Nur dan Priantinah (2012) maupun Ruroh dan Latifah (2018) menunjukkan bahwa leverage berpengaruh terhadap pengungkapan tanggungjawab sosial. Sebaliknya, Robiah dan Erawati (2017) menemukan bahwa leverage tidak berpengaruh terhadap pengungkapan tanggungjawab sosial perusahaan.

Ukuran Dewan Komisaris. Dewan komisaris merupakan wakil shareholder dalam entitas bisnis yang berbadan hukum Perseroan Terbatas (PT) yang berfungsi mengawasi pengelolaan perusahaan yang dilaksanakan oleh manajemen (direksi), dan bertanggungjawab untuk menentukan apakah manajemen memenuhi tanggungjawab mereka dalam mengembangkan dan menyelenggarakan pengendalian intern perusahaan (Mulyadi, 2002:185). Dewan komisaris sebagai puncak dari pengelolaan internal perusahaan, memiliki peranan terhadap aktivitas pengawasan. Komposisi dewan komisaris menentukan kebijakan perusahaan termasuk praktek dan pengungkapan CSR. Coller dan Gregory (1999) dalam Sembiring (2003) menyatakan bahwa semakin besar jumlah anggota dewan komisaris maka akan semakin mudah untuk mengendalikan CEO dan pengawasan yang dilakukan akan semakin efektif. Penelitian yang dilakukan oleh Susilatri et al. (2011) maupun Nur dan Priantinah (2012) menunjukkan bahwa ukuran dewan komisaris berpengaruh terhadap pengungkapan tanggungjawab sosial perusahaan. Sebaliknya, Oktariani dan Mimba (2014) menemukan bahwa ukuran dewan komisaris tidak berpengaruh terhadap pengungkapan tanggungjawab sosial perusahaan.

Profitabilitas. Rasio profitabilitas merupakan rasio untuk menilai kemampuan perusahaan dalam mencari keuntungan (Kasmir, 2014:196). Rasio ini juga memberikan ukuran tingkat efektivitas manajemen suatu perusahaan. Pada penelitian ini profitabilitas diproksikan dengan Return on Aset (ROA) sesuai hasil penelitian Susilatri et al. (2011) dan Ruroh dan Latifah (2018). Profitabilitas yang tinggi akan memberikan kesempatan yang lebih kepada manajemen dalam mengungkapkan serta melakukan program CSR. Semakin tinggi profitabilitas suatu perusahaan, maka manajer lebih termotivasi untuk memberikan informasi rinci termasuk kebebasan untuk menunjukkan dan mempertanggungjawabkan seluruh program sosialnya. Hal ini menyebabkan manajer ingin meyakinkan investor akan profitabilitas perusahaan yang tinggi (Ruroh dan Latifah, 2018). Penelitian yang dilakukan oleh Ruroh dan Latifah (2018) maupun Wahyuningsih dan Mahdar (2018) menunjukkan bahwa profitabilitas berpengaruh terhadap pengungkapan tanggungjawab sosial perusahaan. Sebaliknya, Nur dan Priantinah (2012) menemukan bahwa profitabilitas tidak berpengaruh pada pengungkapan tanggungjawab sosial perusahaan.

\section{METODE PENELITIAN}

Jenis dan sumber data. Penelitian ini merupakan penelitian asosiatif (hubungan), yaitu suatu rumusan masalah penelitian yang bersifat menanyakan hubungan antara dua variabel atau lebih (Sugiyono, 2017:36). Berdasarkan jenis data dan analisis yang digunakan, penelitian ini termasuk penelitian kuantitatif karena mengacu pada perhitungan data yang 
berupa angka. Sumber data dalam penelitian ini merupakan data sekunder yang diperoleh secara historis dari laporan keuangan yang telah dipublikasikan perusahaan pertambangan yang go public dan terdaftar di Bursa Efek Indonesia.

Sampel dan teknik pengambilan sampel. Populasi dalam penelitian ini adalah perusahaan sektor pertambangan yang terdaftar di Bursa Efek Indonesia (BEI) pada tahun 2016-2018 dengan jumlah sebanyak 44 perusahaan. Pengambilan sampel dilakukan menggunakan teknik non-probability sampling dengan metode purposive sampling yaitu pengambilan sampel dengan kriteria-kriteria tertentu. Kriteria sampel dalam penelitian ini adalah sebagai berikut.

a. Perusahaan sektor pertambangan yang sudah terdaftar di Bursa Efek Indonesia periode tahun 2016-2018 secara berturut-turut.

b. Perusahaan sektor pertambangan yang sudah melakukan publikasi laporan keuangan tahunan (annual report) yang telah diaudit selama periode tahun 2016-2018.

c. Perusahaan mengungkapkan data yang diperlukan dalam penelitian secara lengkap selama periode 2016-2018.

Berdasarkan kriteria yang telah ditetapkan oleh metode purposive sampling, maka sampel dalam penelitian ini sebanyak 17 perusahaan dengan total observasi sebanyak 51 laporan keuangan perusahaan. Tabel 1 menyajikan operasionalisasi variabel yang digunakan dalam penelitian ini.

Tabel 1. Definisi operasional variabel

\begin{tabular}{ll}
\hline \multicolumn{1}{c}{ Variabel } & \multicolumn{1}{c}{ Rumus } \\
\hline Pengungkapan CSR/CSR Index (CSRI) & (Skor Pengungkapan CSR : Skor \\
& Maksimum Pengungkapan CSR) x 100\% \\
Ukuran Perusahaan (SIZE) & Logaritma natural dari total aset \\
Leverage & (Jumlah hutang : Jumlah ekuitas) x 100\% \\
Ukuran Dewan Komisaris (UDK) & Jumlah total dewan komisaris \\
Profitabilitas (ROA) & (Laba bersih : Total aktiva) x 100\% \\
\hline
\end{tabular}

Metode analisis. Analisis yang digunakan untuk mengetahui seberapa besar suatu variabel independen mempengaruhi variabel dependen dilakukan dengan metode analisis regresi linier berganda pada tingkat signifikansi 0,05 .

1. Analisis statistik deskriptif. Pengukuran yang digunakan adalah nilai minimum, nilai maksimum, nilai rata-rata, standar deviasi dan range.

2. Pengujian hipotesis

1. Uji asumsi klasik

Uji normalitas. Uji normalitas bertujuan untuk menguji apakah residual error model regresi terdistribusi normal atau tidak. Salah satu model yang banyak digunakan untuk menguji normalitas adalah dengan uji Jarque-Bera. Uji Jarque-Bera mempunyai nilai Chi-Square dengan derajat bebas dua. Jika hasil uji Jarque-Bera lebih besar dari nilai Chi-Square pada $\alpha=5 \%$, maka hipotesis nol diterima yang berarti residual error dari model regresi berdistribusi normal. Jika hasil uji Jarque-Bera lebih kecil dari nilai Chi-Square pada $\alpha=5 \%$, maka hipotesis nol ditolak yang artinya residual error dari model regresi tidak berdistribusi normal.

Uji multikolinearitas. Pengujian multikolinieritas bertujuan untuk menguji apakah pada model regresi ditemukan adanya korelasi antar variabel independen. Jika hasil penelitian menunjukkan nilai Variance Inflation Factor (VIF) $\geq 10$ berarti ada multikolinearitas, sebaliknya jika nilai VIF $<10$ berarti bebas multikolinearitas.

Uji heteroskedastisitas. Heteroskedastisitas merupakan suatu pelanggaran asumsi dalam persamaan regresi berganda dimana residual error memiliki varians yang tidak 
konstan antar periode pengamatan. Heteroskedastisitas menyebabkan hasil estimasi dengan OLS akan menghasilkan parameter yang bias, tidak efisien maupun konsisten, artinya koefisien yang dihasilkan bukan dari varians residual error terkecil. Dalam penelitian ini, uji untuk melihat apakah terdapat heterokedastisitas dalam suatu model regresi adalah dengan menggunakan White-test.

2. Koefisien korelasi dan koefisien determinasi. Korelasi merupakan teknik analisis yang termasuk dalam salah satu teknik pengukuran asosiasi/hubungan. Pengukuran asosiasi merupakan istilah umum yang mengacu pada sekelompok teknik dalam statistik bivariat yang digunakan pada sekelompok teknik dalam statistik bivariat yang digunakan untuk mengukur kekuatan hubungan antara dua variabel. Koefisien determinasi dimana pengujian ini menguji sejauh mana variasi dari variabel terikat mampu dijelaskan oleh variabel bebasnya. Nilai $\mathrm{R}^{2}$ merupakan fraksi dari variasi yang mampu dijelaskan oleh variabel bebas terhadap variabel terikat, dimana nilai $\mathrm{R}^{2}$ berkisar antara 0-1 persen dan jika nilai mendekati 1 maka semakin baik.

3. Analisis regresi berganda. Estimasi parameter model dengan data panel, mengunakan beberapa teknik yaitu:

Model common effect (ordinary least square). Model ini merupakan model yang paling sederhana. Dalam estimasinya diasumsikan bahwa setiap untit individu memiliki intercept dan slope yang sama (tidak ada perbedaan pada dimensi ketat waktu). Dengan kata lain, regresi data panel data yang dihasilkan akan berlaku untuk setiap individu.

Model efek tetap (the fixed effect model). Model efek tetap adalah model regresi data panel yang didapatkan dengan asumsi bahwa unit cross section dan time series yang digunakan dalam model sudah diketahui terlebih dahulu, FEM dalam penelitian ini memiliki konstanta yang bervariasi pada unit cross section dan koefisien konstanta yang mengasumsikan bahwa perbedaan pengaruh dari unit cross section dan time series tercermin dari konstanta yang berbeda-beda.

Model efek random (the random effect model). Model ini disebut juga model komponen error. Sama seperti model efek tetap, model ini juga memungkinkan terjadi perbedaan nilai parameter intercept dan koefisien berbeda antar daerah dan antar waktu, yang diekspresikan dalam error. Pada model ini gangguan diasumsikan bersifat acak untuk seluruh populasi. Model ini mengasumsikan bahwa error secara individu tidak saling berkorelasi, begitu juga dengan error kombinasinya. Dengan menggunakan model ini maka kita dapat menghemat pemakaian derajat kebebasan dan tidak mengurangi jumlah seperti pada fixed effect model. Hal ini berimplikasi pada parameter hasil estimasi akan menjadi efisien.

\section{HASIL PENELITIAN DAN PEMBAHASAN}

\subsection{Hasil penelitian}

Variabel penelitian yang digunakan dalam penelitian ini meliputi ukuran perusahaan (size), leverage, ukuran dewan komisaris (UDK), dan profitabilitas (ROA) sebagai variabel independen, pengungkapan corporate social responsibility (CSRI) sebagai variabel dependen. Tabel 2 menunjukkan bahwa variabel size, leverage, UDK dan CSRI memiliki nilai rata-rata lebih besar dari nilai standar deviasi. Hal ini menunjukkan bahwa kualitas data dari variabel tersebut baik karena nilai rata-rata yang lebih besar dari nilai standar deviasinya, mengidentifikasikan bahwa standar error dari variabel tersebut kecil. Sedangkan variabel ROA memiliki nilai rata-rata yang lebih kecil dari nilai standar deviasi sehingga dapat diidentifikasi bahwa standar error dari variabel tersebut besar. 
Tabel 2. Statistik deskriptif

\begin{tabular}{lccccc}
\hline & CSRI & SIZE & LEVERAGE & UDK & \multicolumn{1}{c}{ ROA } \\
\hline Mean & 0.651961 & 6.460175 & 0.499901 & 3.941176 & 0.011345 \\
Median & 0.642857 & 6.424304 & 0.489615 & 4.000000 & 0.017733 \\
Maximum & 1.000000 & 7.942668 & 1.067488 & 7.000000 & 0.211853 \\
Minimum & 0.416667 & 5.106850 & 0.023549 & 2.000000 & -0.455474 \\
Std. Dev. & 0.176345 & 0.766153 & 0.202360 & 1.528552 & 0.096910 \\
Skewness & 0.488117 & -0.006802 & 0.269118 & 0.269362 & -1.853426 \\
Kurtosis & 2.037808 & 2.197024 & 3.993258 & 1.860146 & 12.24839 \\
Jarque-Bera & 3.992550 & 1.370529 & 2.712052 & 3.377666 & 210.9562 \\
Probability & 0.135840 & 0.503957 & 0.257683 & 0.184735 & 0.000000 \\
Sum & 33.25000 & 329.4689 & 25.49495 & 201.0000 & 0.578573 \\
Sum Sq. Dev. & 1.554872 & 29.34953 & 2.047475 & 116.8235 & 0.469575 \\
Observations & 51 & 51 & 51 & 51 & 51 \\
\hline
\end{tabular}

Uji asumsi klasik. Gambar 1 menunjukkan bahwa nilai Jarque-Bera sebesar 3,116077 dengan nilai probabilitas sebesar 0,210549. Dimana nilai probabilitas lebih besar dari 0,05 yang berarti bahwa nilai residual error berdistribusi normal.

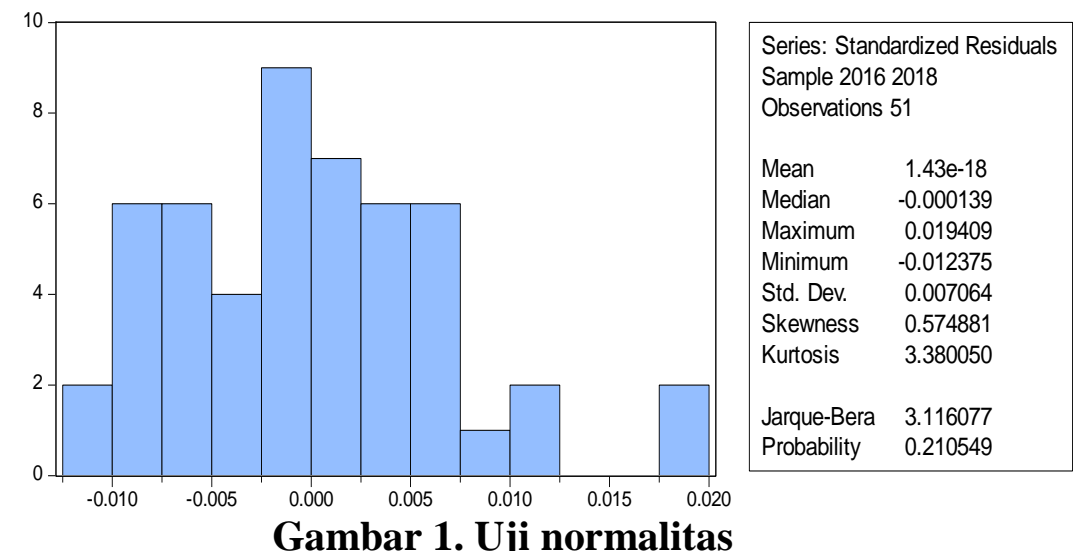

Table 3 menunjukkan bahwa nilai Centered Variance Inflation Factors (VIF) dari variabel size, leverage, ukuran dewan komisaris dan profitabilitas memiliki nilai VIF dari 10 , sehingga dapat disimpulkan bahwa tidak terjadi multikolinearitas antar variabel independen dalam model penelitian ini.

Tabel 3. Uji multikolinearitas

\begin{tabular}{|c|c|}
\hline Variabel & VIF \\
\hline SIZE & 1.872263 \\
\hline LEVERAGE & 1.084565 \\
\hline UDK & 1.830641 \\
\hline ROA & 1.323824 \\
\hline
\end{tabular}

SIZE adalah ukuran perusahaan, UDK adalah ukuran dewan komisaris, ROA adalah return on asset (rasio profabilitas)

Tabel 4 menunjukkan bahwa hasil uji heterokedastitas memiliki nilai probabilitas Chi-Square sebesar 0,3590 yang lebih besar dari $\geq 0,05$ sehingga hal ini berarti bahwa tidak ada gejala heteroskedastisitas yang terjadi. 
Tabel 4. Uji heteroskedastisitas

\begin{tabular}{lccc}
\hline F-statistic & 1.100451 & Prob. F(14,36) & 0.3898 \\
Obs*R-squared & 15.28455 & Prob. Chi-Square(14) & 0.3590 \\
Scaled explained SS & 8.382040 & Prob. Chi-Square(14) & 0.8685 \\
\hline
\end{tabular}

Tabel 5 menunjukkan bahwa semua variabel independen berkorelasi dengan variabel dependen. Hal ini berarti bahwa antara variabel independen memiliki hubungan dengan variabel dependen.

Tabel 5. Analisis korelasi

\begin{tabular}{lccccc}
\hline & CSRI & SIZE & LEVERAGE & UDK & ROA \\
\hline CSRI & 1.000000 & 0.645529 & -0.040401 & 0.766395 & 0.472237 \\
SIZE & 0.645529 & 1.000000 & 0.092367 & 0.639377 & 0.462383 \\
LEVERAGE & -0.040401 & 0.092367 & 1.000000 & 0.244980 & 0.168574 \\
UDK & 0.766395 & 0.639377 & 0.244980 & 1.000000 & 0.406449 \\
ROA & 0.472237 & 0.462383 & 0.168574 & 0.406449 & 1.000000 \\
\hline
\end{tabular}

Pengujian hipotesis. Pengujian hipotesis dilakukan dengan melakukan analisis regresi berganda melalui beberapa model pengujian yaitu common effect model, fixed effect model dan random effect model. Tahap pertama yang dilakukan yaitu uji Chow, dimana Tabel 6 menunjukkan bahwa hasil uji Chow memiliki nilai probabilitas pada F-test sebesar 0,0000 dan nilai Chi-Square sebesar 0,0000, kedua nilai tersebut lebih kecil dari 0,05 sehingga dapat disimpulkan bahwa model mengikuti Fixed Effect Model (FEM).

Tabel 6. Uji Chow

\begin{tabular}{lccc}
\hline \multicolumn{1}{c}{ Effects Test } & Statistic & d.f. & Prob. \\
\hline Cross-section F & 351.114373 & $(16,30)$ & 0.0000 \\
Cross-section Chi-square & 267.129294 & 16 & 0.0000 \\
\hline
\end{tabular}

Tahap kedua yang dilakukan yaitu Uji Hausman, dimana Tabel 7 menunjukkan bahwa hasil uji Hausman memiliki nilai Chi-Square sebesar 0,0000 dan lebih kecil dari 0,05 sehingga dapat disimpulkan bahwa menurut uji Hausman, model mengikuti Fixed Effect Model (FEM).

\section{Tabel 7. Uji Hausman}

\begin{tabular}{cccc}
\hline Test Summary & Chi-Sq. Statistic & Chi-Sq. d.f. & Prob. \\
\hline Cross-section random & 29.044901 & 4 & 0.0000 \\
\hline
\end{tabular}

Tabel 8 menunjukkan bahwa nilai probabilitas ukuran perusahaan (size) terhadap CSRI adalah sebesar 0,8450 $(>0,05)$ dalam arti bahwa ukuran perusahan tidak berpengaruh terhadap CSRI, nilai probabilitas leverage terhadap CSRI adalah sebesar 0,5309 $(>0,05)$ dalam arti bahwa leverage tidak berpengaruh terhadap CSRI, nilai probabilitas ukuran dewan komisaris (UDK) terhadap CSRI adalah sebesar 0,8728 $(>0,05)$ dalam arti bahwa ukuran dewan komisaris tidak berpengaruh terhadap CSRI, dan nilai probabilitas ROA terhadap CSRI adalah sebesar 0,0026 $(<0,05)$ dalam arti bahwa ROA berpengaruh terhadap CSRI. Tabel 8 menunjukkan bahwa nilai R-Squared sebesar 0,998395 sehingga besarnya nilai koefisien determinasi adalah sebesar 99,83\%. Hal ini menunjukkan bahwa variasi dari variabel terikat yang mampu dijelaskan oleh variabel bebas adalah sebesar 99,83\%. Persamaan regresi yang dihasilkan adalah sebagai berikut.

$\mathrm{Y}=0,645130+0,002643$ SIZE - 0,017978 LEVERAGE - 0,000476 UDK + 0,071933 ROA 
Tabel 8. Analisis regresi berganda dengan fixed effect model

\begin{tabular}{lcc}
\hline \multicolumn{1}{c}{ Variable } & Coefficient & Prob. \\
\hline Constant & 0.645130 & 0.0000 \\
SIZE & 0.002643 & 0.8450 \\
LEVERAGE & -0.017978 & 0.5309 \\
UDK & -0.000476 & 0.8728 \\
ROA & 0.071933 & 0.0026 \\
R-squared & 0.998395 & \\
SIZE adalah ukuran perusahaan, UDK adalah ukuran dewan komisaris, ROA adalah return on asset (rasio \\
profabilitas)
\end{tabular}

\subsection{Pembahasan}

Pengaruh ukuran perusahaan (size) terhadap pengungkapan CSR (CSRI).

Berdasarkan Tabel 8, variabel ukuran perusahaan (size) menunjukkan koefisien regresi positif sebesar 0,002643 dengan nilai probabilitas lebih besar dari 0,05 yaitu 0,8450. Hal ini berarti bahwa tingkat signifikansinya lebih besar dari $\alpha=5 \%$, sehingga hipotesis ke-1 tidak didukung atau $\mathrm{H}_{1}$ ditolak. Dapat disimpulkan bahwa semakin besar ukuran perusahaan dengan total jumlah aset perusahaan pertambangan tidak menuntut besarnya tanggung jawab terhadap pengungkapan akan aksi sosial terhadap lingkungan, masyarakat sekitar, tenaga kerja dan sebagainya. Penelitian ini tidak mendukung Susilatri et al. (2011), Nur dan Priantinah (2012), Robiah dan Erawati (2017) serta Ruroh dan Latifah (2018). Secara teoritis, seharusnya perusahaan dengan aset yang besar akan lebih mengungkapkan program sosialnya sebagai hubungan responsibilitas dan akuntabilitas terhadap stakeholdernya dan penciptaan nilai positif sebagai dampak dari aktivitas perusahaan dibandingkan dengan perusahaan yang nilai asetnya lebih kecil.

Pengaruh leverage terhadap pengungkapan CSR (CSRI). Berdasarkan Tabel 8, variabel leverage menunjukkan koefisien regresi negatif sebesar -0,017978 dengan nilai probabilitas lebih besar dari 0,05 yaitu 0,5309 . Hal ini berarti bahwa tingkat signifikansinya lebih besar dari $\alpha=5 \%$, sehingga hipotesis ke-2 tidak didukung atau $\mathrm{H}_{2}$ ditolak. Dapat disimpulkan bahwa tinggi rendahnya tingkat leverage perusahaan tidak mempengaruhi luas pengungkapan tanggung jawab sosial perusahaan. Semakin tinggi tingkat leverage semakin besar kemungkinan akan melanggar perjanjian kredit sehingga perusahaan akan berusaha untuk melaporkan laba sekarang lebih tinggi, agar laba yang dilaporkan tinggi maka manajemen harus mengurangi biaya-biaya termasuk biaya untuk mengungkapkan $C S R$. Penelitian ini mendukung Robiah dan Erawati (2017), dimana leverage tidak berpengaruh terhadap pengungkapan corporate social responsibility. Hal ini disebabkan oleh karena sudah terjadi hubungan yang baik antara perusahaan dengan debtholders, yang mengakibatkan debtholders tidak terlalu memperhatikan rasio leverage perusahaan. Penelitian ini tidak mendukung Nur dan Priantinah (2012) maupun Ruroh dan Latifah (2018) yang menyatakan bahwa leverage berpengaruh terhadap pengungkapan corporate social responsibility.

Pengaruh ukuran Dewan Komisaris (UDK) terhadap pengungkapan CSR (CSRI). Berdasarkan Tabel 8, variabel ukuran dewan komisaris (UDK) menunjukkan koefisien regresi negatif sebesar $-0,000476$ dengan nilai probabilitas lebih besar dari 0,05 yaitu 0,8728 . Hal ini berarti bahwa tingkat signifikansinya lebih besar dari $\alpha=5 \%$, sehingga hipotesis ke-3 tidak didukung atau $\mathrm{H}_{3}$ ditolak. Penelitian ini membuktikan bahwa ukuran dewan komisaris sebuah perusahaan tidak berpengaruh terhadap pengungkapan CSR. Ini berarti bahwa semakin banyak jumlah anggota dewan komisaris dalam suatu perusahaan, maka pengungkapan tanggung jawab sosial perusahaan tidak akan semakin luas walaupun mempunyai peranan pengawasan dan mempunyai peranan untuk menjaga hubungan yang baik terhadap stakeholder dan juga ukuran dewan komisaris tidak mempunyai kecenderungan 
dalam memberikan legitimasi dalam praktek pengungkapan sosial perusahaan. Penelitian ini mendukung penelitian yang dilakukan oleh Oktariani dan Mimba (2014), dimana ukuran dewan komisaris tidak berpengaruh terhadap pengungkapan corporate social responsibility. Penelitian ini tidak mendukung Susilatri et al. (2011) maupun Nur dan Priantinah (2012) yang menyatakan bahwa variabel ukuran dewan komisaris memiliki pengaruh signifikan terhadap pengungkapan corporate social responsibilty.

Pengaruh profitabilitas (ROA) terhadap pengungkapan CSR. Berdasarkan Tabel 8, variabel $R O A$ menunjukkan koefisien regresi positif sebesar 0,071933 dengan nilai probabilitas lebih kecil dari 0,05 yaitu 0,0026. Hal ini berarti bahwa tingkat signifikansinya lebih kecil dari $\alpha=5 \%$, sehingga hipotesis ke-4 dapat terdukung atau $\mathrm{H}_{0}$ ditolak. Bahwa besar kecilnya profitabilitas akan mempengaruhi tingkat pengungkapkan CSR. Hasil penelitian ini mendukung teori legitimasi yang dinyatakan oleh Sembiring (2003), Ruroh dan Latifah (2018), dan Wahyuningsih dan Mahdar (2018) bahwa profitabilitas berpengaruh terhadap pengungkapan tanggung jawab sosial perusahaan. Hal ini didukung dengan asumsi bahwa ketika perusahaan memiliki tingkat laba yang tinggi, perusahaan (manajemen) menganggap perlu melaporkan hal-hal yang dapat mengganggu informasi tentang sukses keuangan perusahaan. Semakin tinggi profitabilitas suatu perusahaan, maka manajer lebih termotivasi untuk memberikan informasi yang lebih terperinci termasuk kebebasan untuk menunjukkan dan mempertanggungjawabkan seluruh program sosialnya dengan tujuan agar para pengguna laporan dapat menangkap "good news" dari kinerja sosial dan lingkungan yang telah dilakukan perusahaan.

\section{KESIMPULAN DAN SARAN \\ 5.1. Kesimpulan}

Berdasarkan pembahasan atas permasalahan maka dapat disimpulkan bahwa ukuran perusahaan, leverage dan ukuran dewan komisaris tidak berpengaruh terhadap pengungkapan corporate social responsibility. Sebaliknya, profitabilitas berpengaruh terhadap pengungkapan corporate social responsibility pada perusahaan pertambangan yang terdaftar di BEI pada periode 2016-2018.

\subsection{Saran}

Penelitian selanjutnya diharapkan dapat menggunakan sampel penelitian yang tidak hanya dari sektor pertambangan tetapi juga mencakup sektor industri lainnya yang terdaftar di Bursa Efek Indonesia (BEI) agar mewakili pengungkapan CSR diseluruh sektor industri yang ada. Penelitian selanjutnya agar dapat menggunakan alat metodologi yang berbeda seperti wawancara langsung dengan ditentukan pendapat mereka tentang tingkat pengungkapan CSR. Selain itu, selanjutnya diharapkan dapat menambah variabel-variabel lain yang diduga mempengaruhi pengungkapan $C S R$.

\section{DAFTAR PUSTAKA}

ACCA. (2013). The business benefits of sustainability reporting in Singapore. Association of Chartered Certified Accountants.

http://www.accaglobal.com/content/dam/acca/global/PDF-technical/otherPDFs/sustainability-roundtable.pdf

Cahya, B. A. (2010). Analisis pengaruh kinerja keuangan terhadap tanggung jawab sosial perusahaan (Corporate Social Responsibility): Studi pada bank di Indonesia periode tahun 2007-2008. Skripsi. Universitas Diponegoro. http://eprints.undip.ac.id/23017/ 
Ambarini, N. (2010). Corporate Social Responsibility (CSR) sebagai instrumen hukum ekonomi di era globalisasi. Jurnal Dinamika Hukum, 10(3), 308-318. http://dx.doi.org/10.20884/1.jdh.2010.10.3.101

Burhan, A. H. N., \& Rahmawati, W. (2012). The impact of sustainability reporting on company performance. Journal of Economics, Business, and Accountancy Ventura Volume, 15(2), 257-272. https://journal.perbanas.ac.id/index.php/jebav/article/view/79

Ghozali, I., \& Chariri, A. (2007). Teori akuntansi. Semarang: Badan Penerbit Universitas Diponegoro

Hadi, N. (2011). Corporate Social Responsibility. Yogjakarta: Graha Ilmu

Kasmir. (2014). Analisis laporan keuangan. Jakarta: Rajawali Pers.

Krivačić, D. (2017). Sustainability reporting quality: The analysis of companies in Croatia. Journal of Accounting and Managememt, 7(1), 1-14.https://hrcak.srce.hr/194710

Lindblom, C. K. (1994). The implications of organizational legitimacy for corporate social performance and disclosure. Conference paper, Critical Perspectives on Accounting Conference, New York.

Loh, L., Thomas, T., \& Wang, Y. (2017). Sustainability reporting and firm value: Evidence from Singapore-listed companies. Sustainability, 9(11), 1-12. https://doi.org/10.3390/su9112112

Mulyadi. (2002). Auditing, Jilid 1, Edisi Enam. Jakarta: Salemba Empat.

Nur, M., \& Priantinah, D. (2012). Analisis faktor - faktor yang mempengaruhi pengungkapan corporate social responsibility di Indonesia. Jurnal Nominal, 1(2), 22-34. https://doi.org/10.21831/nominal.v1i2.996

Oktariani, N. W., \& Mimba, N. P. S. H. (2014). Pengaruh karakteristik perusahaan dan tanggung jawab lingkungan pada pengungkapan tanggung jawab sosial perusahaan. E-Jurnal Akuntansi, 6(3), 402-418. https://ojs.unud.ac.id/index.php/Akuntansi/article/view/8333

Shaukat, A., Qiu, Y., \& Trojanowski, G. (2016). Board attributes, corporate social responsibility strategy, and corporate environmental and social performance. Journal of Business Ethics, Springer, 135(3), 569-585. https://link.springer.com/article/10.1007/s10551-014-2460-9

Robiah, A. M., \& Erawati, T. (2017). Pengaruh leverage, size dan kepemilikan manajemen terhadap CSR dislosure. Jurnal Akuntansi Dewantara, 1(1), 39-48. http://jurnal.ustjogja.ac.id/index.php/akuntansidewantara/article/view/23

Ruroh, I. N., \& Latifah, S. W. (2018). pengaruh profitabilitas, leverage, ukuran perusahaan, dan risk minimization terhadap pengungkapan Corporate Social Responsibility (CSR). Jurnal Akademi Akuntansi, 1(1), 42-53. https://doi.org/10.22219/jaa.v1i1.6952

Sembiring, E. R. (2003). Pengaruh karakteristik perusahaan terhadap pengungkapan tanggung jawab sosial: Studi empiris pada perusahaan yang tercatat (go public) di Bursa Efek Jakarta. Thesis. Universitas Diponegoro. http://eprints.undip.ac.id/9941/

Sugiyono. (2017). Metode penelitian kuantitatif, kualitatif dan R\&D. Bandung: Alfabeta

Susilatri, Agusti, R., \& Indriani, D. (2011). Pengaruh leverage, profitabilitas, size, umur perusahaan dan ukuran dewan komisaris terhadap pengungkapan tanggung jawab sosial perusahaan. Jurnal Pendidikan Ekonomi dan Bisnis, 3(1), 412-428. https://pekbis.ejournal.unri.ac.id/index.php/JPEB/article/view/406

Wahyuningsih, A., \& Machdar, N. M. (2018). Pengaruh size, leverage dan profitabilitas terhadap pengungkapan CSR pada perusahaan manufaktur yang terdaftar di Bursa Efek Indonesia. Jurnal Bisnis dan Komunikasi, 5(1), 27-36. http://research.kalbis.ac.id/Research/Files/Article/Full/QP7CMK1Q9CHIAT2JCRDL OFABQ.pdf 